\section{Pelatihan \\ PENYUSUNAN \\ PELAPORAN PPH \\ BADAN BAGI UMKM \\ KECAMATAN SEKAYU \\ KABUPATEN MUSI \\ BANYUASIN}

\author{
Ameilia Damayanti ${ }^{1}$, Susilawati ${ }^{2}$, \\ Ahmad Ali Akbar Aslamy ${ }^{2}$ \\ ${ }^{1,2,3)}$ Fakultas Ekonomi dan Bisnis, \\ Universitas Pancasila \\ Article history \\ Received : 9/03/2021 \\ Revised : 6/04/2021 \\ Accepted : 6/05/2021
}

*Corresponding author

Email : amel.damay@univpancasila.ac.id

\begin{abstract}
Abstraksi
Pajak merupakan kontribusi wajib kepada negara yang terutang oleh orang pribadi atau badan yang bersifat memaksa berdasarkan Undang-Undang dengan tidak mendapatkan imbalan langsung dan digunakan untuk keperluan negara bagi kemakmuran rakyat. Saat ini, pertumbuhan UMKM berkembang dengan pesat, hal ini tidak terlepas dari pembebanan pajak yang harus disetorkan oleh pelaku UMKM dan besarnya setoran tersebut berdasarkan ketentuan yang sudah dijelaskan dalam PP Nomor 46 tahun 2013. FEB Universitas Pancasila bekerjasama dengan Program Pembangunan dan Pemberdayaan Masyarakat Desa (P3MD) Kementrian Desa Pembangunan Daerah Tertinggal dan Transmigrasi Kabupaten Musi Banyuasin Provinsi Sumetera Selatan dalam memberikan webinar pelatihan penyusunan pelaporan PPh Badan bagi UMKM. Pelatihan yang diberikan merukan pelatihan agar UMKM bisa memahami tentang PPh Badan, kemudian bisa menghitung, menyusun serta melaporkan PPh Badan setiap periodenya. Metode pelaksanaan pengabdian masyarakat ini dilakukan dengan cara pemberian materi perpajakan, pajak penghasilan (PPh) Badan, dan mengisi e-spt. Peserta UMKM di Kecamatan Sekayu Kabupaten Musi Banyuasin, Sumatera Selatan memiliki kemampuan dalam menghitung dan menyusun pelaporan pajak usahanya.
\end{abstract}

Keywords: Penyusunan Pelaporan, PPh Badan, UMKM, e-spt

\begin{abstract}
Taxes are mandatory contributions to the state that are owed by private persons or entities that are compelling based on law without receiving direct compensation and are used for the state`s needs for the welfare of the people. At present, the growth of UMKM is growing rapidly, this is inseparable from the tax imposition that must be deposited by UMKM and the amount of the deposit is based on the provisions that have been described in PP NO 46 of 2013. FEBUP collaborates with the village community development and empowerment program (P3MD) Ministry of Villages for disadvantages areas and transmigration of Musi Banyuasin Regency, South Sumatra Province in providing training webinars for the preparation of corporate income tax reporting for UMKM. The training provided is training so that UMKM can understand about corporate income tax, then can compile and report corporate income tax each period. The method or step for implementing community service are carried out by providing taxation material, income taxes, and e-spt. UMKM participants in Sekayu district, Musi Banyuasin Regency, South Sumatera have the ability to calculate and compile their business tax reports.
\end{abstract}

Keywords: compilation of reports, corporate inome tax, UMKM, e-spt

\section{PENDAHULUAN}

Pembayaran pajak merupakan perwujudan dari kewajiban kenegaraan dan peran serta wajib pajak untuk secara langsung bersamasama melaksanakan kewajiban perpajakan untuk pembiayaan negara dan pembangunan 
nasional. Sesuai Sesuai falsafah undangundang perpajakan, membayar pajak bukan hanya merupakan kewajiban, tetapi merupakan hak dari setiap warga Negara untuk ikut berpartisipasi dalam bentuk peran serta terhadap pembiayaan negara dan pembangunan nasional.

Usaha Mikro, Kecil dan Menengah (UMKM) memiliki peranan penting dalam pembangunan nasional yaitu penyerapan tenaga kerja, pemerataan pendapatan, pembangunan ekonomi pedesaan, peningkatan ekspor nonmigas, serta peningkatan Produk Domestik Bruto (Fidela, 2020). Saat ini, pertumbuhan UMKM berkembang dengan pesat, pertumbuhan UMKM tersebut tidak terlepas dari pembebanan pajak yang harus disetorkan oleh pelaku UMKM. Besarnya setoran tersebut berdasarkan ketentuan yang sudah dijelaskan dalam PP Nomor 46 Tahun 2013. UMKM memang mampu bertahan krisis global dan terus mengalami pertumbuhan, namun pada kenyataannya banyak permasalahan yang dihadapi oleh UMKM sendiri dan lebih berat. Hal itu dapat terjadi karena selain dipengaruhi secara tidak langsung dengan adanya persaingan secara global, UMKM juga harus menghadapi persoalan secara internal di daerah sekitar UMKM tersebut seperti masalah upah buruh, adanya pungutan liar dan lain sebagainya (Jaya, 2020).

Menurut sebagian besar para pelaku UMKM, semakin besar usaha yang dijalankan maka semakin besar pula kewajiban yang harus mereka lakukan. Hal itu yang menyebabkan UMKM sulit untuk berkembang pada saat ini. Ditambah dengan adanya pemberlakuan pajak membuat semakin besar pula biaya yang ditanggung para pelaku UMKM. Biaya yang ditanggung pelaku UMKM akan mempengaruhi laba bersih yang diperoleh selama ini. UMKM tersebut harus membayar pajak, membayar upah buruh sesuai dengan UMP, sementara untuk kegiatan usaha mereka saat ini hanya membayar upah buruh di bawah
UMP. Alasan itu yang membuat para pelaku UMKM cenderung tidak akan mengembangkan usahanya (Kuncoro, 2013). Sebagian besar pelaku UMKM jarang mengadministrasikan laporan keuangannya secara tertulis, meskipun transaksi yang dijalankan bernilai miliaran rupiah. Hal tersebut yang membuat pelaku UMKM sulit untuk mengetahui omzet dan laba yang diperoleh secara tepat. Jumlah omzet yang tidak diketahui memungkinkan wajib pajak dari para pelaku UMKM menyetorkan pajak dengan jumlah yang tidak sesuai dari seharusnya. Berdasarkan kenyataan tersebut maka diperlukan seseorang dari bidang akuntansi. Terdapat beberapa keterbatasan selain dalam hal administrasi pada UMKM yaitu, rendahnya kualitas sumber daya manusia, teknologi, sumber daya produktif seperti modal, informasi dan pasar. UMKM sulit berinovasi dalam menghasilkan produk sehingga hal itu membuat perekonomian Indonesia tidak berkembang. UMKM yang dapat berinovasi dalam objek penjualannya, maka penjualan juga akan meningkat.

\section{TUJUAN KEGIATAN}

Kegiatan Pelatihan ini bertujuan untuk meningkatkan pemahaman dan kesadaran pelaku UMKM di Kecamatan Sekayu Kabupaten Musi Banyuasin untuk menghitung, membayar dan melaporkan Pajak Penghasilan Badan UMKM. Pelatihan ini adalah sebagai wujud nyata peran Fakultas Ekonomi dan Bisnis Universitas Pancasila (FEBUP) dan pemerintah daerah kabupaten Musi Banyuasin Kecamatan Sekayu dalam peningkatan kesadaran pembayaran dan pelaporan perpajakan khususnya pada pelaku UMKM.

\section{TARGET LUARAN}

Adapun target luaran dari kegiatan pengabdian masyarakat ini adalah sebagai berikut :

1. Sasaran kepesertaan dari kegiatan ini adalah pelaku UMKM yang aktif di Kabupaten Musi Banyuasin 
2. Kegiatan ini diharapkan dapat meningkatkan kemampuan para pelaku UMKM di Kecamatan Sekayu Kabupaten Musi Banyuasin dalam pelaporan e-spt dan memanfaatkan aplikasi digital Dirjen Pajak untuk mencatat dan melaporkan transaksi keuangannya, sehingga dapat memudahkan pelaku UMKM dalam menghitung dan melaporkan pajak penghasilan usahanya.

3. Produk pengabdian ini berupa dokumen yang berisi modul pembuatan pelaporan espt yang bisa dimanfaatkan oleh pelaku UMKM dan dinas terkait untuk jangka panjang, serta rekaman video tutorial penggunaan aplikasi digital Dirjen Pajak untuk perhitungan pajak penghasilan.

\section{METODE PELAKSANAAN}

Pengabdian kepada masyarakat berupa pelatihan pembuatan pelaporan e-spt ini diperuntukkan kepada UMKM yang aktif dan beroperasi di Kabupaten Musi Banyuasin, dimana usaha tersebut telah terdaftar pada Dinas Pemberdayaan Masyarakat dan Desa Kabupaten Musi Banyuasin. Waktu pengabdian dilakukan pada tanggal 20 Januari 2021. Sebelum kegiatan pengabdian dilaksanakan, Unit Penelitian dan Pengabdian (P2M) Fakultas Ekonomi dan Bisnis Universitas Pancasila (FEB-UP) melakukan komunikasi melalui telepon dengan Dinas Pemberdayaan Masyarakat dan Desa Kabupaten Musi Banyuasin. Dikarenakan kondisi di Indonesia yang sedang dilanda oleh pandemi virus Corona, maka seluruh aktivitas pengabdian dilakukan secara daring melalui media Zoom.

Selanjutnya, pihak Dinas terkait memberikan informasi terkait dengan data peserta UMKM yang telah mendaftar dan bersedia mengikuti kegiatan pengabdian kepada masyarakat. Dari data yang diperoleh dari Dinas terkait terdapat 25 pelaku usaha yang terdiri dari 5 usaha kecil dalam bentuk
UKM dan 20 BUMDES dengan berbagai jenis usaha seperti mini market, penyewaan, agen gas, warung sembako, fotocopy, dan lainnya. Supaya kegiatan pelatihan berjalan secara efektif dan efisien, setiap peserta diminta untuk menyatakan kesediaannya mengikuti seluruh sesi pelatihan dan pendampingan yang ditawarkan. Hal ini bertujuan sebagai antisipasi agar pelaku usaha tidak hanya hadir di awal sesi saja, tetapi hadir di seluruh sesi kegiatan sehingga menerima materi secara utuh, karena pelatihan dan pendampingan ini bersifat sistematis. Setelah seluruh persiapan dan kesepakatan dengan peserta UMKM, selanjutnya kegiatan pengabdian masyarakat dilaksanakan sesuai dengan waktu yang telah ditentukan sebelumnya

\section{PEMBAHASAN \\ Proses Kegiatan}

Kegiatan pengabdian kepada masyarakat kali ini yaitu memberikan pelatihan dan demonstrasi pembuatan pelaporan keuangan dengan menggunakan aplikasi digital Dirjen Pajak berupa e-spt secara daring dengan menggunakan aplikasi Zoom. Kegiatan dimulai dengan membuat grup pada aplikasi whatsapp dengan tujuan agar dapat memudahkan koordinasi dengan tim pengabdian dan peserta UMKM. Dikarenakan seluruh kegiatan dilakukan secara daring, maka pembagian tugas kepada anggota tim dosen yang terlibat selama acara didiskusikan seluruhnya melalui grup whatsapp dan zoom.

Selanjutnya, anggota tim dosen lainnya bertugas dan berperan aktif dalam menjawab pertanyaan dan membantu peserta pelatihan melalui media chat yang tersedia di Zoom selama acara dilaksanakan. Setelah semua persiapan telah dilakukan, selanjutnya kegiatan pengabdian masyarakat dengan tema pelatihan penyusunan pelaporan $\mathrm{PPh}$ Badan bagi UMKM Kecamatan Sekayu Kabupaten Musi Banyuasin dilaksanakan. 


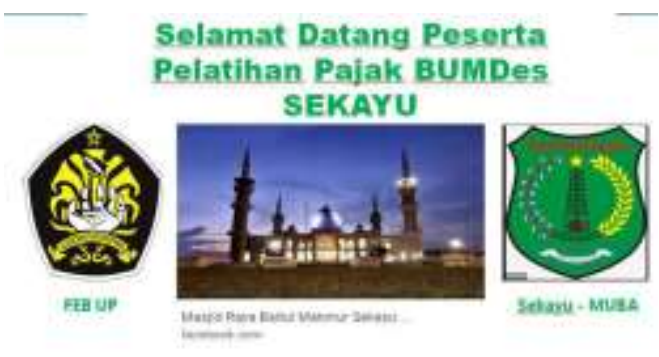

Gambar 1. Pelaksanaan Pelatihan

Kegiatan ini diawali dengan sambutan oleh Dekan Fakultas Ekonomi dan Bisnis Universitas Pancasila Ibu Dr. Iha Haryani Hatta, SE., MM, kemudian sambutan oleh Kepala Dinas Pemberdayaan Masyarakat dan Desa Kabupaten Musi Banyuasin Bapak H. Richard Chahyadi, AP, M.Si dan terakhir dari Ibu Katri Gentari, SE., MM selaku Tenaga Ahli Pelayanan Sosial Dasar Kabupaten Musi Banyuasin. Setelah sambutan, acara dilanjutkan dengan pemaparan materi pelaihan yang dilakukan oleh narasumber yaitu Ibu Ameilia Damayanti, SE., M.Ak dan Ibu Susilawati, SE., M.Ak.

\section{Tutorial e Spt Badan}

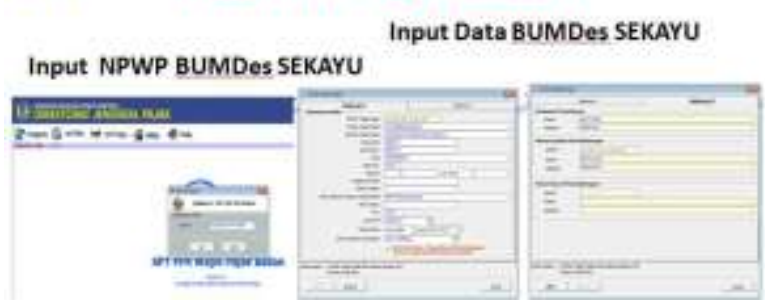

Gambar 2. Pemaparan Materi

Selama pelatihan berlangsung, peserta dapat bertanya secara langsung kepada narasumber maupun tim dosen melalui media chat pada ZOOM. Beberapa peserta menanyakan terkait

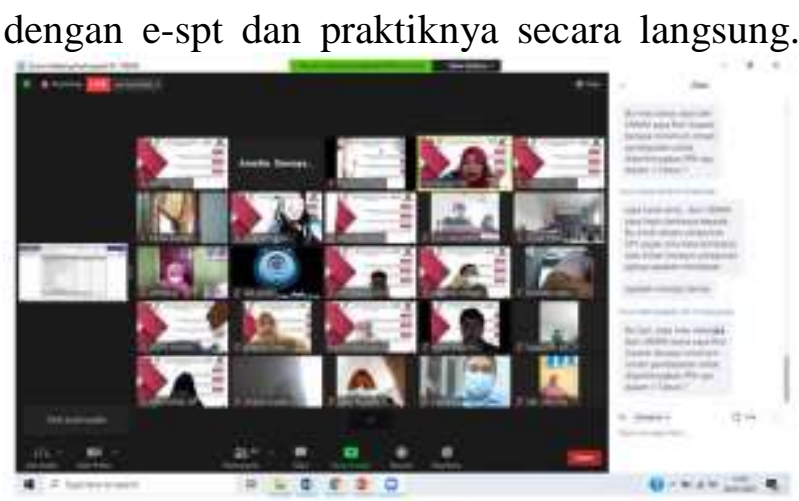

Gambar 3. Sesi Tanya Jawab

\section{Hasil Pelaksanaan Kegiatan}

Pengabdian masyarakat merupakan suatu kegiatan yang bertujuan untuk membantu masyarakat tertentu dalam beberapa aktivitas (Menristekdikti, 2016). Program ini secara umum dirancang oleh Perguruan Tinggi sesuai dengan Tri Dharma pemenuhan kegiatan kerja dari para dosennya. Selain itu, kegiatan ini juga dapat memberikan kontribusi nyata bagi masyarakat.

Perkembangan teknologi yang cepat menuntut para pelaku UMKM untuk tetap up to date dengan kemajuan system tak terkecuali pada system perpajakn. e-Filing pajak lahir dari penerapan sistem Modul Penerimaan Negara Generasi Kedua (MPN G2) yang mulai dijalankan pada tahun 2007. Dalam sistem ini, negara menggunakan surat elektronik serta pembayaran dengan e-billing sebagai bagian dari sistem transaksinya. Menurut situs resmi kementerian keuangan, sistem ini berlaku baik untuk penerimaan negara yang berbentuk pajak maupun bukan pajak. Direktorat Jenderal Pajak adalah salah satu pihak penerima tagihan resmi (biller) di kementerian keuangan. Pemerintah kemudian membuat situs khusus untuk mendukung e-Filing dan e- Billing yakni sse.pajak dan efiling.pajak. Akan tetapi, situssitus ini memiliki sistem yang terpisah dari situs resmi DJP. Pada tahun 2014, DJP menyatukan semua layanan pelaporan dan pembayaran pajak di bawah satu sistem. DJP juga membuat situs DJP Online 
(djponline.pajak.go.id) sebagai pusat pelayanan SPT elektronik

Para peserta UMKM diberikan wawasan terkait pentingnya aplikasi e-spt untuk perhitungan dan pelaporan pajak penghasilan. Namun, karena keterbatasan pada saat pelaksanaan acara yang dilakukan secara daring, tidak seluruh peserta dapat mempraktekan secara langsung karena beberapa peserta pelatihan mengakses ZOOM melalui handphone. Sehingga, selama pelaksanaan pelatihan direkam menggunakan fasilitas rekaman yang ada pada ZOOM.

Secara umum, pelaksanaan pengabdian ini berdampak positif, pelaksanaan pengabdian berdampak positif terhadap hal penting bagi para pelaku usaha yang rutin mengikuti serangkaian agenda pelatihan dan pendampingan. Pertama, mengetahui jumlah keuntungan/kerugian usaha secara tepat. Dengan adanya sistem pelaporan online, pelaku usaha diwajibkan untuk tertib dalam melakukan segala transaksi pada bisnis. Kedua, memudahkan dalam menghitung, membayar dan melaporkan pajak terhutang. Sistem pembukuan yang efektif dan efisien dapat membantu pelaku usaha untuk melakukan penghitungan dan pelaporan pajak penghasilan terhutang. Salah satu contoh yang sangat terlihat adalah bagi pelaku usaha yang bergerak di sektor makanan dan minuman, pelaku usaha akan sangat mudah menghitung dan melaporkan pajak penghasilan terhutangnya

\section{KESIMPULAN}

Sebagian besar peserta pelatihan di Kabupaten Musi Banyuasin dapat memahami pelatihan yang diberikan walaupun masih banyak peserta UMKM yang belum paham tentang pajak dan e-spt. Tetapi pada kegiatan ini para pelaku UMKM memiliki minat dan keinginan yang kuat untuk membayar pajak penghasilannya dan sudah mempelajari penggunaan aplikasi e-spt yang memudahkan pelaku UMKM untuk melakukan perhitungan, pembayaran, dan pelaporan pajak penghasilan secara berkala.

Dengan adanya pemahaman perpajakan dan espt, UMKM di Indonesia khususnya kecamatan Sekayu Kabupaten Musi Banyuasin dapat memperoleh pemahaman tentang perpajakan yang lebih baik dan dapat disiplin membayar pajak untuk berkontribusi positif terhadap kemajuan perekonomian Negara.

\section{SARAN}

Adapun saran yang bisa direkomendasikan yaitu :

1. Model pelatihan seperti ini juga dapat dijadikan sebagai model pendampingan pelengkap bagi instansi pemerintahan yang rutin mengadakan pembinaan UMKM, dengan menambahkan aspek monitoring dan evaluasi secara berkala untuk mengukur efektivitas pelatihan dan pendampingan.

2. Diharapkan adanya kesinambungan kegiatan dan evaluasi sehingga para pelaku UMKM di Kecamatan Sekayu Kabupaten Musi Banyuasin dapat berkontribusi dalam pengembangan ekonomi di Indonesia.

\section{PUSTAKA}

Fidela, Alifah., Pratama, Aprinaldi., Nursyamsiah, Tita., 2020. Pengembangan Usaha Mikro Kecil dan Menengah (UMKM) dengan Program Pemasaran Desa Jambu Raya di Desa Jambu, Kabupaten Sumedang. Jurnal Pusat Inovasi Masyarakat, Vol 2(3) 2020; 493-498

Jaya, I Made Laut Mertha,.., Ilahiyah, Elthaf Mar`a., 2020, Pembinaan Implementasi Efilling bagi Pelaku UMKM Kerupuk di Kecamatan Gunung ANyar Kota Surabaya, Jurnal Ilmiah Padma Sri Kreshna Vol 2 No 2

Kuncoro, M., 2013. Metode Riset Untuk Bisnis dan Ekonomi. Edisi 4. Jakarta: Erlangga 
Ameilia Damayanti dkk, Abdi Implementasi Pancasila: Jurnal Pengabdian Masyarakat, Volume. 1 Nomor 1, Mei 2021: Nomor Halaman DOI:

Menristekdikti., 2016. Panduan Pelaksanaan Penelitian dan Pengabdian Masyarakat di Perguruan Tinggi Edisi X tahun 2016, Hal.4 Pemerintah Nomor 46 Tahun 2013 tentang Pajak Penghasilan atas Penghasilan dari Usaha yang Diterima atau Diperoleh Wajib Pajak yang Memiliki Peredaran Bruto Tertentu (PP46/2013)

Purba, M.A., 2019, Analisis Penerapan SAK EMKM Pada Penyusunan Laporan Keuangan UMKM Di Kota Batam. Jurnal Akuntansi Barelang, 3(2), 55. https://doi.org/10.33884/jab.v3i2.1219

Tarmizi, R., Bugawanti, N.L.S., 2013, Pengaruh Persepsi Pengusaha Kecil dan Menengah Terhadap Penggunaan SAK ETAP di Kota Bandar Lampung. ISSN 2087-2054, 5(2) 